\title{
Influence of superabsorbent polymers on the chemical composition of strawberry (Fragaria $\times$ ananassa Duch.) and biological activity in the soil
}

\author{
Grzegorz Mikiciuk ${ }^{1 *}$, Malgorzata Mikiciuk ${ }^{2}$, Matgorzata Hawrot-Paw $w^{3}$ \\ ${ }^{1}$ Department of Horticulture \\ West Pomeranian University of Technology \\ Slowackiego 17, 71-790 Szczecin, Poland \\ ${ }^{2}$ Department of Plant Physiology and Biochemistry \\ West Pomeranian University of Technology \\ Slowackiego 17, 71-790 Szczecin, Poland \\ ${ }^{3}$ Department of Microbiology and Environmental Biotechnology \\ West Pomeranian University of Technology \\ Slowackiego 17, 71-790 Szczecin, Poland
}

\begin{abstract}
By improving the air and water properties of soils, superabsorbent polymers can affect the increase and improvement of the quality of the yield of berry plants, including strawberries. Their presence in the soil has an influence on its biological activity as related to microorganisms. The aim of the research was to assess the influence of superabsorbent polymers added to the soil on the content of macroelements and sodium in the leaves and fruit of strawberry of the 'Elsanta' cultivar and changes in the number of soil bacteria, actinomycetes and fungi. The superabsorbent polymer (AgroHydroGel) was used in two doses: 1.8 and $3.6 \mathrm{~g} \mathrm{dm}^{-3}$ of soil. The content of phosphorus, potassium, calcium, magnesium and sodium was assessed using the ASA method, while the content of nitrogen and sulphur was assessed by the elemental analysis method (CHNS analyser). The number of microorganisms was assessed with a BacTrac analyser and the coefficient of microorganism development extent (SR) was also determined. AgroHydroGel increased the content of nitrogen and potassium in leaves and fruit but did not affect the content of phosphorus, sulphur and sodium. The addition of the superabsorbent at a dose of $3.6 \mathrm{~g} \mathrm{dm}^{-3}$ of soil reduced the magnesium content both in the leaves and fruit of the strawberry. AgroHydroGel decreased the content of calcium in the fruit. The use of AgroHydroGel contributed to the expansion of the $\mathrm{K}$ ion ratio to other ions, both in the leaves and fruits. We observed a significant increase in the amount of soil bacteria $\left(1.8 \mathrm{~g} \mathrm{dm}^{-3} \mathrm{dose}\right)$ and no significant influence on actinomycetes and fungi (irrespective of dose used).
\end{abstract}

Key words: hydrogels, fruit, leaves, macroelements, microorganisms, strawberry

\section{INTRODUCTION}

Superabsorbent polymers are employed in agriculture and horticulture to improve the physical properties of soil, and in particular to increase its water capacity. Due to their high water absorbency, the use of hydrogels increases the resistance of plant to water stress (Johnson and Leach 1990, Geesing and Schmidhalter 2004, Makowska and Borowski

\footnotetext{
*Corresponding author.

Tel.: +48914496161;

e-mail: grzegorz.mikiciuk@zut.edu.pl (G. Mikiciuk).
} 
2004, Sojka et al. 2007). Water deficit in soil evidently results in a decrease in the quantity and quality of berry fruit yields, including strawberry (Klamkowski et al. 2006, Klamkowski and Treder 2008).

According to many authors, superabsorbent polymers also have a beneficial effect on plant nutrient uptake, and increase the saturation of the sorption complex with bases, which prevents leaching losses of nutrients, thereby increasing the effectiveness of fertilization, and conduces to environmental protection (Mikkelsen1994, Guiwei and De Varennes 2009, Kim et al. 2010). As many researchers have stated, superabsorbent polymers also bind heavy metals and decrease their availability for plants (De Varennes and Torres 1999, Kos and Leštan 2003, De Varennes et al. 2006, Guiwei and De Varennes 2009). According to Mikiciuk and Mikiciuk (2010a), the use of hydrogel reduces the accumulation of zinc and lead in the leaves and copper, nickel and lead in the fruit of strawberry. Adding AgroHydroGel to soil also results in an increase of the content of extract and L-ascorbic acid, and in a decrease of nitrate and nitrite accumulation in strawberry fruit (Mikiciuk and Mikiciuk 2010b).

Superabsorbent polymers introduced into soil have an influence on its biological activity related to microorganisms. However, changes in microflora after hydrogel application are ambiguous, since both stimulations and reductions in the number and activity of microorganisms have been observed. This can be affected by season, employed measures or type of cultivated plant, which additionally impacts other significant variables, e.g. the content of nutrients (Sojka et al. 2006).

Gel polymers can also affect soil enzymatic activity. They can increase the activity of dehydrogenases, protease, urease, phosphatase or cellulase (Šarapatka et al. 2004, De Varennes and Queda 2005).

The aim of the conducted research was to determine the influence of superabsorbent polymers (AgroHydroGel) added to soil on the content of macroelements and sodium in the leaves and fruit of the 'Elsanta' strawberry cultivar and on biological activity in the soil.

\section{MATERIAL AND METHODS}

Pot experiments in a completely randomized design were carried out in four replicates (one pot per one replication) in the years 2007-2008 in a vegetation hall of the West Pomeranian University of Technology in Szczecin. The object was the 'Elsanta' strawberry cultivar. The experimental factor was the addition of a superabsorbent polymer with the trade name of AgroHydroGel to the soil. It is a cross-linked hydrophilic polyacrylamide gel polymer whose dried coils are in a form of crystalline white grains with a diameter of 0.1 $-4 \mathrm{~mm}$, and their water absorption capacity is from 300 to $500 \mathrm{~cm}^{3} \mathrm{~g}^{-1}$ (Paluszek and Żembrowski 2008). The superabsorbent polymer was used in two doses: 1.8 and $3.6 \mathrm{~g} \mathrm{dm}^{-3}$ of soil. Kick's pots with a volume of $10 \mathrm{dm}^{3}$ were filled with $8 \mathrm{dm}^{3}$ of soil. Table 1 shows the basic physicochemical soil parameters and content of assimilable forms of macroelements. Frigo plants were planted in mid-April 2007. Fertilization of all plants was at doses of 50, 80 and $100 \mathrm{~kg}$ NPK ha ${ }^{-1}$. Potassium, phosphorus and half of the nitrogen fertilizer were used before the planting. The remaining nitrogen dose was applied before strawberry flowering. All of the plants were watered according to indications of a soil moisture tensiometer (placed in the soil with the addition of the superabsorbent polymer $-1.6 \mathrm{~g} \mathrm{dm}^{-3}$ of soil) amounting to $450 \mathrm{hPa}$. Watering was performed with $0.5 \mathrm{dm}^{3}$ of water per pot. Plants were overwintered in an unheated greenhouse. The fruit for the analysis were gathered systematically as they were ripening (five times in the first and six times in the second year of the study), from the first ten-day period of June to the first ten-day period of July. A collective sample was created for each replication from the gathered fruit. The leaves were gathered in the second ten days of July (in both years of the experiment), after the fruiting of strawberry (a collective sample was created for each replication). Fully ripe fruit and healthy developed

Table 1. The properties of soil

\begin{tabular}{|c|c|c|c|c|c|c|c|c|c|c|}
\hline \multicolumn{2}{|c|}{$\mathrm{pH}$} & \multirow{2}{*}{$\begin{array}{c}\text { Clay } \\
\text { fraction } \\
(\%)\end{array}$} & \multirow{2}{*}{$\underset{\left(\mathrm{g} \mathrm{cm}^{-3}\right)}{\mathrm{S}^{*}}$} & $\mathrm{Pkw}$ & $\mathrm{Pkv}$ & Wtw & Wtv & $\mathrm{P}$ & K & $\mathrm{Mg}$ \\
\hline $\mathrm{H}_{2} \mathrm{O}$ & $\mathrm{KCl}$ & & & \multicolumn{4}{|c|}{$(\%)$} & \multicolumn{3}{|c|}{$\left(\mathrm{mg} 100 \mathrm{~g}^{-1}\right)$} \\
\hline 6.58 & 5.97 & 21 & 1.24 & 24.7 & 34.0 & 32.9 & 38.0 & 11.8 & 14.3 & 5.10 \\
\hline
\end{tabular}

*So - bulk density, Pkw - capillary weight, Pkv - capillary volume, Wtw - total water capacity - weight, Wtv - total water capacity - volume 
leaves from the middle plant parts were collected. The average weight of a laboratory sample of dried leaves and fruit for one replication was about $30 \mathrm{~g}$. The content of macronutrients and sodium in the fruit and leaves of strawberry was determined in each laboratory sample in three replications. Plant material was mineralized in a mixture of 3:1 of nitric acid (V) and chloric acid (VII) for assessments of phosphorus, potassium, calcium, magnesium and sodium levels. The content of the aforementioned elements was assessed using the ASA method (SOLAR 939). The content of general nitrogen and sulphur was determined using an elemental analysis method with a CHNS analyser (Costech). The presented results of the content of macronutrients and sodium in the leaves and fruit are the mean of two vegetative seasons.

The number of microorganisms was assessed on the basis of impedance measurement - apparent resistance, with a BacTrac analyser (SyLab Austria), according to a method developed by Nowak and Hawrot (1998). Soil samples for microbiological analysis were taken from the plants' rhizosphere in each of the four pots (at the end of the experiment). Liquid culture media suitable for individual groups of examined microorganisms were used in the assessments: for bacteria - a medium with soil extract according to Bunt and Rovira (1955); for actinomycetes - a medium according to Cyganov and Zukov (1964); and for fungi - Martin's medium (1950). All determinations were made in three replications. The results were calculated into dry matter and given as colony-forming units (CFU) in $1 \mathrm{~g}$ of soil. Additionally, the coefficient of microorganism development extent (SR) according to Myśków (1981) was determined, which expresses the ratio of the number of bacterial and actinomycetal cells to the number of fungal cells.
The obtained results were analysed with onefactor analysis of variance. In order to determine the significance of differences between mean values, Duncan confidence half-intervals were calculated at a significance level of $\mathrm{p}=0.05$.

\section{RESULTS AND DISCUSSION}

The addition of superabsorbent polymer to soil significantly increased the content of nitrogen both in the leaves and fruit of the examined cultivar (Tab. 2). According to Michalski and Wieniarska (2003), its content in the leaves of the control plants should be considered scarce, while it was low in the leaves of plants growing in soil with the addition of superabsorbent polymer (1.8 and $3.6 \mathrm{~g} \mathrm{dm}^{-3}$ of soil). A tendency for an increase of nitrogen content in grasses after the use of superabsorbent polymers was demonstrated by Breś (2006), and in lettuce leaves by Wierzbicka and Makowska-Gadomska (2005). A different opinion was expressed by Geesing and Schmidhalter (2004), according to whom the addition of hydrogel to soil did not affect the content of nitrogen in wheat leaves. The literature on the subject lacks reports about the influence of superabsorbent polymers on the accumulation of macroelements in fruit.

The content of phosphorus in the leaves of the examined cultivar should be regarded as optimum values (Jarosz et al. 2011). No influence of the superabsorbent polymer on the accumulation of the nutrient in the leaves and fruit of the examined plant was observed (Tab. 2). Similar research results were obtained by Breś (2006) for grasses and by Wierzbicka and Makowska-Gadomska for lettuce (2005).

The use of the superabsorbent polymer significantly increased the potassium content

Table 2. Influence of AgroHydroGel on the content of macroelements and sodium in the leaves and fruit of 'Elsanta' strawberry

\begin{tabular}{lccccccc}
\hline \multirow{2}{*}{ Treatment } & $\mathrm{N}$ & $\mathrm{P}$ & $\mathrm{K}$ & $\mathrm{Ca}$ & $\mathrm{Mg}$ & $\mathrm{S}$ & $\mathrm{Na}$ \\
\cline { 2 - 8 } & \multicolumn{7}{c}{$\mathrm{G} \mathrm{kg}^{-1}$ dry matter } \\
\hline Control & $15.8 \mathrm{a}^{*}$ & $2.75 \mathrm{a}$ & $15.7 \mathrm{a}$ & $9.06 \mathrm{a}$ & $2.36 \mathrm{~b}$ & $0.92 \mathrm{a}$ & $41.1 \mathrm{a}$ \\
$1.8 \mathrm{~g} \mathrm{dm}^{-3}$ soil & $18.6 \mathrm{~b}$ & $2.84 \mathrm{a}$ & $18.0 \mathrm{~b}$ & $9.14 \mathrm{a}$ & $2.18 \mathrm{~b}$ & $1.01 \mathrm{a}$ & $42.9 \mathrm{a}$ \\
$3.6 \mathrm{~g} \mathrm{dm}^{-3}$ soil & $18.8 \mathrm{~b}$ & $2.87 \mathrm{a}$ & $18.1 \mathrm{~b}$ & $9.13 \mathrm{a}$ & $1.69 \mathrm{a}$ & $1.02 \mathrm{a}$ & $41.4 \mathrm{a}$ \\
\hline & & & Fruit & & & \\
\hline Control & $9.76 \mathrm{a}$ & $2.31 \mathrm{a}$ & $15.9 \mathrm{a}$ & $2.97 \mathrm{~b}$ & $1.32 \mathrm{~b}$ & $0.53 \mathrm{a}$ & $47.6 \mathrm{a}$ \\
$1.8 \mathrm{~g} \mathrm{dm}^{-3}$ soil & $10.64 \mathrm{~b}$ & $2.28 \mathrm{a}$ & $17.6 \mathrm{~b}$ & $2.71 \mathrm{a}$ & $1.30 \mathrm{ab}$ & $0.52 \mathrm{a}$ & $44.8 \mathrm{a}$ \\
$36 \mathrm{~g} \mathrm{dm}^{-3}$ soil & $10.54 \mathrm{~b}$ & $2.55 \mathrm{a}$ & $19.3 \mathrm{c}$ & $2.56 \mathrm{a}$ & $1.27 \mathrm{a}$ & $0.52 \mathrm{a}$ & $46.4 \mathrm{a}$ \\
\hline
\end{tabular}

*Means assigned the same letters do not differ significantly at the level of significance $p=0.05$ 


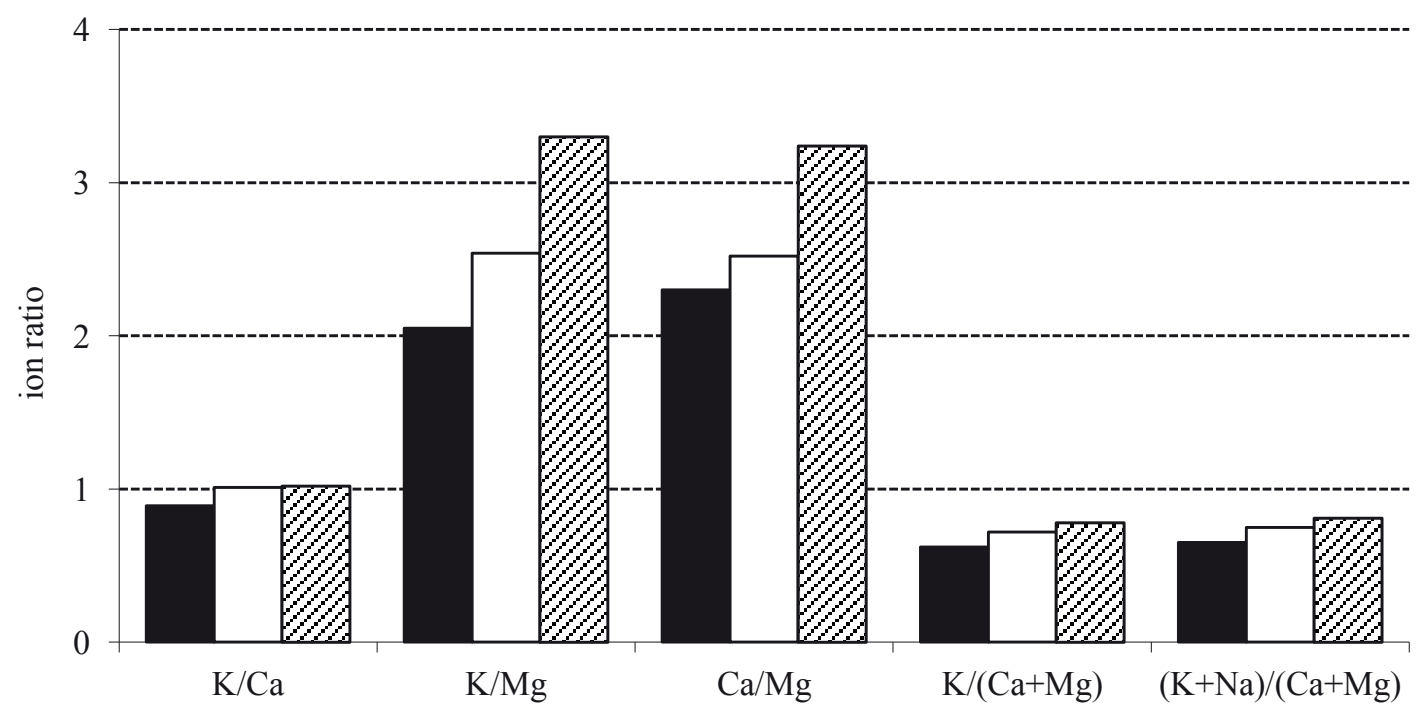

Figure 1. Influence of AgroHydroGel ( $\mathrm{g} \mathrm{dm}^{-3}$ soil) on ion ratio in the leaves of 'Elsanta' strawberry

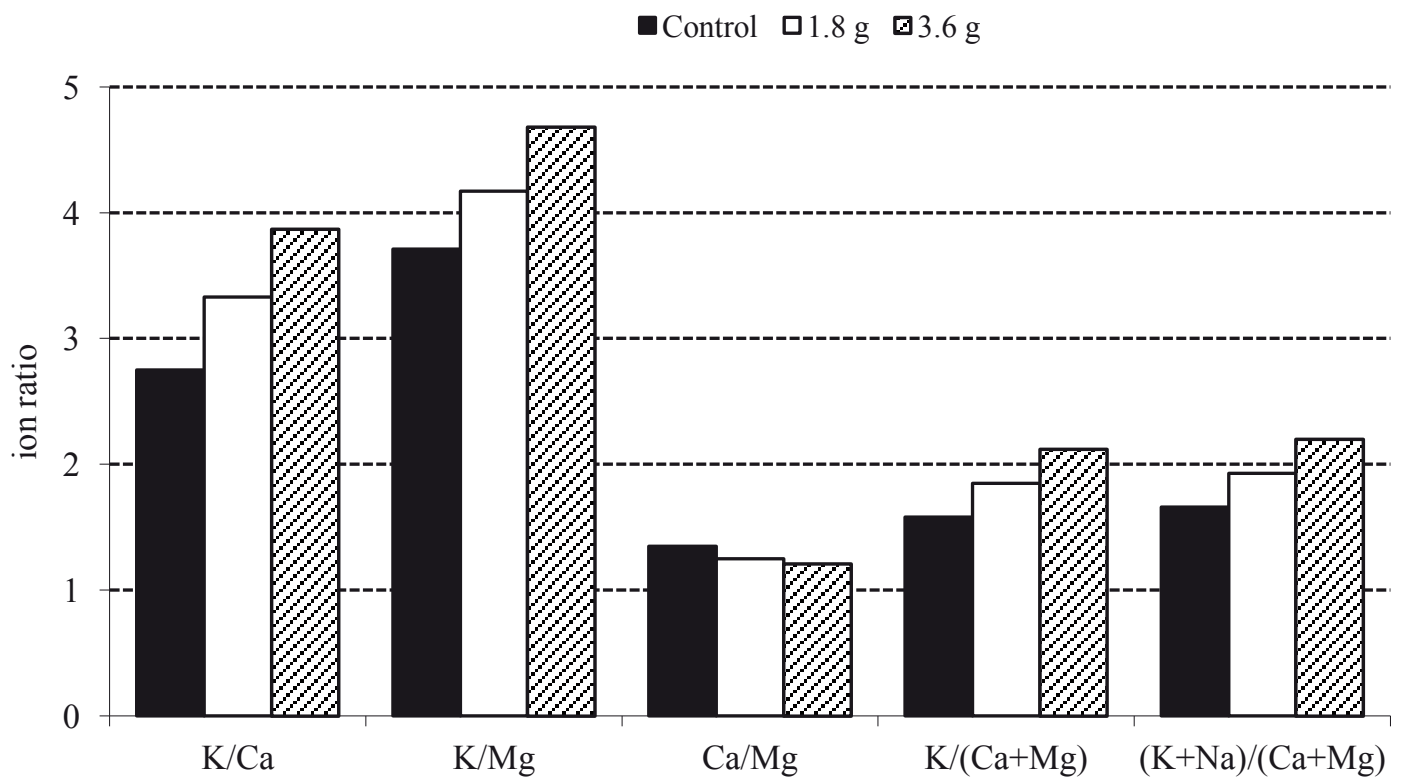

Figure 2. Influence of AgroHydroGel ( $\mathrm{g} \mathrm{dm}^{-3}$ soil) on ion ratio in fruit of 'Elsanta' strawberry

both in the leaves and fruit of strawberry cultivar 'Elsanta' (Tab. 2). The leaves of the control plants and those grown in soil with the addition of hydrogel had an optimum value of this nutrient (Michalski and Wieniarska 2003, Jarosz and Konopińska 2006). According to Wierzbicka and Majkowska-Gadomska (2005), soil-applied Acrygel does not modify the content of potassium in lettuce leaves. The significantly highest potassium content was found in the fruit of plants grown in soil supplemented with superabsorbent polymer at a dose of $3.6 \mathrm{~g} \mathrm{dm}^{-3}$ of soil, while the lowest was in the fruit of the control plants.
We observed no influence of hydrogel in the soil on the content of calcium, sodium and sulphur in strawberry leaves and sodium and sulphur in strawberry fruit. In the case of the fruit, a significant decrease was observed in calcium content in plants growing in soil supplemented with the superabsorbent polymer (Tab. 2). According to Breś (2006), superabsorbent polymer causes a reduction in the content of calcium and an increase in the content of sodium in grasses. However, according to Wierzbicka and Majkowska-Gadomska (2005), hydrogel does not affect the content of calcium in lettuce leaves. 


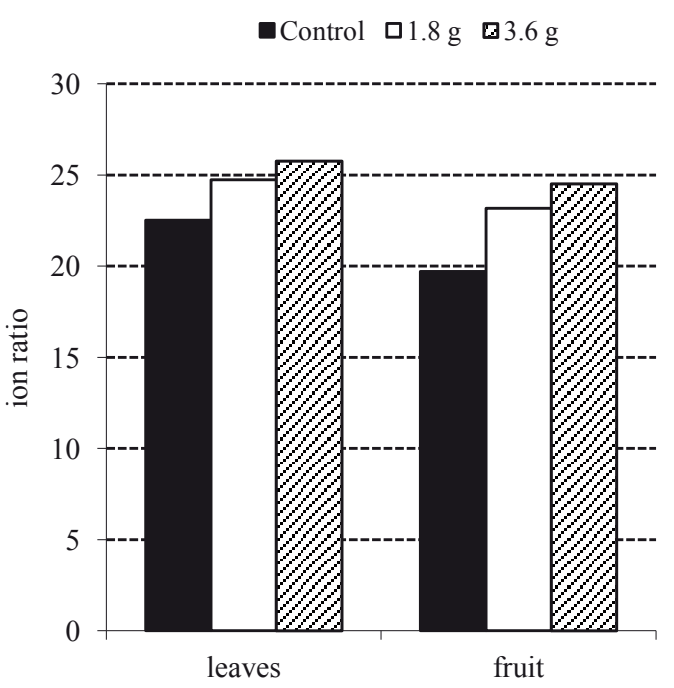

Figure 3. Influence of AgroHydroGel ( $\mathrm{g} \mathrm{dm}^{-3}$ soil) on $\mathrm{K} /$ $\mathrm{Na}$ ratio in the leaves and fruit of 'Elsanta' strawberry

The higher applied dose of superabsorbent polymer ( $3.6 \mathrm{~g} \mathrm{dm}^{-3}$ of soil) caused a decrease of the content of magnesium both in the leaves and fruit of strawberry. The content of this element in the leaves of control plants and plants grown in soil with the addition of the superabsorbent in the dose of $1.8 \mathrm{~g} \mathrm{dm}^{-3}$ of soil can be regarded as optimum values, while that found in the leaves of plants grown in soil with the addition of hydrogel in the dose of $3.6 \mathrm{~g} \mathrm{dm}^{-3}$ of soil was low (Michalski and Wieniarska 2003). Breś (2006) demonstrated a similar relationship of decreasing magnesium content in grasses due to the addition of superabsorbent to soil. Wierzbicka and Majkowska-Gadomska (2005) stated that hydrogel did not affect the content of magnesium in lettuce leaves. Sita et al. (2005) stated that the use of superabsorbent polymers in soil resulted in an increase in the ratio of $\mathrm{K} / \mathrm{Ca}$ and $\mathrm{K} / \mathrm{Mg}$ in chrysanthemum shoots. They accounted the phenomenon to the higher polymer sorption of calcium and magnesium cations than that of potassium. In the present study, changes were also detected in ion ratio in the leaves and fruits (Figs 1, 2 and 3). The use of superabsorbent polymers resulted in an increase in the ratio of $\mathrm{K} / \mathrm{Ca}, \mathrm{K} / \mathrm{Mg}$,
$\mathrm{K} / \mathrm{Na}, \mathrm{K} /(\mathrm{Ca}+\mathrm{Mg})$ and $(\mathrm{K}+\mathrm{Na}) /(\mathrm{Ca}+\mathrm{Mg})$, both in the leaves and fruits, and $\mathrm{Ca} / \mathrm{Mg}$ in the leaves. The use of superabsorbent polymers resulted in a narrowing of the $\mathrm{Ca} / \mathrm{Mg}$ ratio in fruits.

Soil microorganisms determine the physicochemical and, above all, biological properties of the environment. Changes in their number may affect the intensity of their processes of organic matter decomposition, mineralisation or the circulation of nutrients essential for normal plant growth and development. In our experiment, the number of bacteria, actinomycetes and fungi in the control soil was $1.1 \times 10^{6} \mathrm{CFU}, 5.3 \times 10^{5} \mathrm{CFU}$ and 8.4 $\times 10^{4} \mathrm{CFU}$ in $1 \mathrm{~g}$ DM of soil, respectively (Tab. 3). The application of the superabsorbent polymer in a dose of $1.8 \mathrm{~g} \cdot \mathrm{dm}^{-3}$ of soil increased the number of bacterial cells, which may be an indicator of its stimulating effect (El-Hady et al. 2011). An increase in the number of bacteria, actinomycetes and fungi by 113, 16 and 15\%, respectively, after the introduction of $2 \mathrm{~g}$ of hydrogel into the soil was also observed by El-Hady and Abo-Sedera (2006). In those experiments, a two-fold increase in hydrogel dose, to $4 \mathrm{~g}$, increased stimulation to the level of $140 \%$ for bacteria, $55 \%$ for actinomycetes and $31 \%$ for fungi, while in the present research, the number of bacteria was reduced in the soil with an addition of hydrogel in the dose of $3.6 \mathrm{~g} \mathrm{dm}^{-3}$ of soil. Regardless of the dose used, superabsorbent polymers did not have a significant influence on the number of actinomycetes and fungi in the soil. On the basis of the value of the coefficient of microorganism development extent it was concluded that, compared to the other objects (SR $=19$ ), more favourable conditions for the growth and development of bacteria and actinomycetes rather than fungi were noted after the introduction of hydrogel in the amount of $1.8 \mathrm{~g} \mathrm{dm}^{-3}$ of soil into the soil $(\mathrm{SR}=20)$.

Superabsorbent polymers can inhibit the growth of microorganisms by binding them to soil particles or to themselves, which affects the mobility of microorganism cells and limits their access to carbon dioxide and nutrients (Sojka et al. 2006).

Table 3. Microbial counts in the control and AgroHydroGel amended soil

\begin{tabular}{lccc}
\hline \multirow{2}{*}{ Treatment } & \multicolumn{3}{c}{ Microbial count $\left[\right.$ CFU g ${ }^{-1}$ d.m. soil] } \\
\cline { 2 - 4 } & Bacteria $\times 10^{6}$ & Actinomycetes $\times 10^{5}$ & Fungi $\times 10^{4}$ \\
\hline Control & $1.1 \mathrm{~b}^{*}$ & $5.3 \mathrm{a}$ & $8.4 \mathrm{a}$ \\
$1.8 \mathrm{~g} \mathrm{dm}^{-3}$ soil & $1.2 \mathrm{c}$ & $5.7 \mathrm{a}$ & $8.6 \mathrm{a}$ \\
$3.6 \mathrm{~g} \mathrm{dm}^{-3}$ soil & $1.0 \mathrm{a}$ & $5.1 \mathrm{a}$ & $8.0 \mathrm{a}$ \\
\hline
\end{tabular}

*Explanation: see Table 2 
Microorganisms also respond negatively to reduced water content in the environment (Whiteley et al, 2003), which, absorbed by a higher hydrogel dose, could become less available. In addition, the type of cultivation is important. In their study, Jiao et al. (2013) noted an increase in the number of bacteria and fungi in cabbage and spinach cultivation and their reduction in the cultivation of wheat.

\section{CONCLUSIONS}

1. The superabsorbent polymer used increased the content of nitrogen and potassium in strawberry leaves and fruit.

2. The addition of superabsorbent polymers to soil at a dose of $3.6 \mathrm{~g} \mathrm{dm}^{-3}$ reduced the magnesium content in leaves and fruit and did not modify the calcium content in leaves but did decrease its content in fruit.

3. The use of superabsorbent polymers contributed to the expansion of $\mathrm{K}$ ion ratio to other ions, both in the leaves and fruit.

4. Only the introduction of superabsorbent polymer at a dose of $1.8 \mathrm{~g} \mathrm{dm}^{-3}$ stimulated a significant increase in the number of bacteria in the soil.

\section{REFERENCES}

Breś W., 2006. Wpływ hydrożelu Alcosorb AS 400 na stan odżywienia traw gazonowych. Act. Agrophys. 7(4): 859-866.

Bunt J.S., Rovira A.D., 1955. Microbiological studies of some subantarctic soils. J. Soil Sci. 6(1): 119-128.

CrganovV.A.,ZukovR.A., 1964.Morfologobiohimičiskie osobennosti novovo vida actionomiceta. Mikrobiol. 33(5): 863-869.

De Varennes A., Torres M.Q., 1999. Remediation of a long-term copper-contaminated soil using a polyacrylate polymer. Soil Use Manage. 15(4): 230-232.

De Varennes A., Queda C., 2005. Application of an insoluble polyacrylate polymer to copper contaminated soil enhances plant growth and soil quality. Soil Use Manage. 21: 410-414.

De Varennes A., Goss M.J., Mourato M., 2006. Remediation of a sandy soil contaminated with cadmium, nickel, and zinc using an insoluble polyacrylate polymer. Comm. Soil Sci. Plant Anal. 37(11-12): 1639-1649.

El-Hady O., Abo-Sedera S.A., Basta A.H., EL-Saied H., 2011. The role of rice straw-based hydrogels on some soil microorganisms strains. BIO 1: 78-84.

El-Hady O., Abo-Sedera S.A., 2006. Conditioning effect of compost and acrylamide hydrogels on a sandy calcareous soil. II-Physico-bio-chemical properties of the soil. Int. J. Agric. Biol. 8(6): 876 -884 .

Geesing D., Schmidhalter U., 2004. Influence of sodium polyacrylate on the water-holding capacity of three different soils and effects on growth of wheat. Soil Use Manage. 20: 207-209.

Guiwei Q., De VArennes A., 2009. Use of hydrophilic insoluble polymers in the restoration of metalcontaminated soils. Appl. Environ. Soil Sci. ID 790687.

Jarosz Z., DZida K., Bartnik K., 2011 Yielding and chemical composition of 'Honeoye' cultivar strawberries depending on the kind of substratum and nitrogen dose. Acta Sci. Pol., Hortorum Cultus 10(1): 95-104.

Jarosz Z., KonopińSKa J., 2006. Plonowanie i skład chemiczny liści truskawki w zależności od rodzaju podłoża i nawożenia azotem. Act. Agrophys. 7(4): 901-908.

JiAO H., BAi Z., LiU Y., WANG K., HuANG Z., 2013. Impact of superabsorbent polymer and plants on microbial community and petroleum hydrocarbon degradation in contaminated soil. Adv. Mat. Res. 807-809: 353-360.

JoHnSON M.S., LEACH R.T., 1990. Effect of superabsorbent polyacrylamide on efficiency of water use by crop seedlings. J. Sci. Food Agr. 52: 431-434.

Kim S., Iyer G., Nadarajah A., Frantz J.M., SpongberG A.L., 2010. Polyacrylamide hydrogel properties for horticultural applications. Int. J. Polym. Anal. Ch. 15: 307-318.

Klamkowski K., Treder W., Tryngiel-Gać A., 2006. The effects of substrate moisture content on water potential, gas exchange rates, growth, and yield in strawberry plants grown under greenhouse conditions. J. Fruit Ornam. Plant Res. 14: 163-171.

Klamkowski K., Treder W., 2008. Response to drought stress of three strawberry cultivars grown under greenhouse conditions. J. Fruit Ornam. Plant Res. 16: 179-188.

Kos B., LeŠTAN D., 2003. Influence of a biodegradable ([S,S]-EDDS) and nondegradable (EDTA) chelate and hydrogel modified soil water sorption capacity on $\mathrm{Pb}$ phytoextraction and leaching. Plant Soil 253(2): 403-411.

Makowska M., Borowski E., 2004. The influence of the addition of Ekosorb to black soil and sandy soil on the content of water in soil, frost injury of flowers and on fruiting of strawberry. Folia Hort. 16(1): 8793.

MARTIN J.P., 1950. Use of acid rose bengale and streptomycin in the plate method for estimating soil fungi. Soil Sci. 6: 215-233.

MichalsKi P., WieniarsKa J., 2003. Wpływ dokarmiania dolistnego na zawartość składników mineralnych w liściach truskawki. Act. Agrophys. 85: 209-217.

Mikiciuk G., Mikiciuk M., 2010a. Effect of polymer supersorbent added to medium on the content of 
mineral elements in strawberry leaves and fruit. J. Elem. 15(2): 313-319.

Miкiciuк G., Miкiciuk M., 2010b. Evaluation of the direct and subsequent influence of a supersorbent polymer on cropping and rate of gas exchange of strawberry (Fragaria ananassa Duch,) 'Elsanta'. J. Fruit Ornam. Plant Res. 18(2): 93-108.

MikKelSEN R.L., 1994. Using hydrophilic polymers to control nutrient release. Fert. Res. 38: 53-59.

Mrśków W., 1981. Próby wykorzystania wskaźników aktywności mikrobiologicznej do oceny żyzności gleby. Post. Mikrobiol. XX(3-4): 173-192.

Nowak A., Hawrot M., 1998. Ocena liczebności mikroorganizmów w glebach skażonych związkami ropopochodnymi przy zastosowaniu analizatora typu BacTrac 4100. Ekologiczne aspekty mikrobiologii gleby. Rocz. AR w Poznaniu CCLXIX: 223-231.

Paluszer J., Żembrowski W., 2008. Improvement of water-air properties of eroded soils in a loess landscape after the application of agrohydrogel. Ann. Warsaw Univ. of Life Sci. - SGGW. Land Reclam. 39: 85-93.

ŠarapatKa B., Rak L., Bubenikova I., 2004. Effects of hydroabsorbent used on extremely sandy soils on soil biological and biochemical characteristics. Eurosoil 2004, Freiburg, Germany.
Sita R.C.M., Reissmann C.B., Marques R., De Oliveira E., Taffarel A.D., 2005. Effect of polymers associated with $\mathrm{N}$ and $\mathrm{K}$ fertilizer sources on Dendrathema grandiflorum growth and $\mathrm{K}, \mathrm{Ca}$ and $\mathrm{Mg}$ relations. Braz. Arch. Biol. Techn. 48(3): 335-342.

Sojka R.E., Bjorneberg D.L., Entry J.A., Lentzl R.D., ORTS W.J., 2007. Polyacrylamide in agriculture and environmental land management. Adv. Agron. 92: $75-162$.

Sojka R.E., Entry J.A., Fuhrmann J.J., 2006. The influence of high application rates of polyacrylamide on microbial metabolic potential in an agricultural soil. Appl. Soil. Ecol. 32: 243-252.

Whiteley A.S., Griffiths R.I., Bailey M.J., 2003. Analysis of the microbial functional diversity within water-stressed soil communities by flow cytometric analysis and CTC+ cell sorting. J. Microbiol. Meth. 54(2): 257-267.

Wierzbicka B., Majkowska-Gadomska J., 2005. Wpływ akryżelu sodowego na zawartość niektórych składników organicznych i mineralnych mineralnych wybranych odmianach sałaty głowiastej masłowej i kruchej (Lactuca sativa L. var. capitata L.). J. Elem. 10(1): 193-199.

Received November 17, 2014; accepted March 19, 2015 